\title{
Após a visita da indesejada das gentes: luto e memória na Revista Estudos Feministas $(2001-2014) *$
}

\author{
Wilton Carlos Lima da Silva**
}

\section{Resumo}

Os obituários no interior das revistas acadêmicas brasileiras apresentam-se de forma diversa. Desde parágrafos padronizados que buscam simplesmente informar ao público leitor, delimitado pela área de pesquisa ou interesse específico da publicação, enquanto "notícia de falecimento", até o texto mais elaborado, que busca apresentar o perfil de um predecessor ou igual que construiu uma obra $e$ estabeleceu vínculos com seus pares. A Revista Estudos Feministas (REF), atualmente editada na Universidade Federal de Santa Catarina, foi lançada em 1992, e vem ocupando ao longo dos anos uma posição de destaque como publicação pioneira e privilegiada para a divulgação de estudos feministas e de gênero em diversas áreas disciplinares no país. Desde 2001 seus números estão disponibilizados no Scielo, e nesse acervo encontram-se acessíveis quase duas dezenas de homenagens fúnebres, na forma de obituários, publicação de entrevistas póstumas ou ensaios. Buscamos discutir como esse conjunto de textos apresenta uma natureza biográfica e caracteriza uma memória grupal construída $e$ reivindicada, na qual as dimensões de luto $e$ as relações intelectuais $e$ institucionais de uma publicação acadêmica permitem equacionar a dor da perda no universo simbólico do grupo.

Palavras-chave: Obituário, Revista Estudos Feministas, Biografia, Luto.

* Recebido em 04 de outubro de 2015, aceito em 10 de agosto de 2017. Este artigo é resultado parcial de pesquisa que recebe recursos de Bolsa de Auxílio Regular FAPESP (Fundação de Apoio a Pesquisa do Estado de São Paulo), Proc. 2016/19014-0.

** Professor do Departamento de História, da Universidade Estadual Paulista Júlio de Mesquita Filho, (UNESP), Campus de Assis, e coordenador do MEMENTO - Grupo de Pesquisa de Memórias, Trajetórias e Biografias, Assis, SP, Brasil.wilton.silva@ unesp.br / http://orcid.org/0000-0002-1507-8017 
After The Visit of The Unwanted: Mourning and Memory in the Revista Estudos Feministas (2001-2014)

\begin{abstract}
Obituaries, within Brazilian academic journals are presented in various forms, ranging from standardized paragraphs that simply seek to inform readers, and which are determined by the research field or specific interest of the publication as "news of a death". More elaborate texts are also found that present a profile of a predecessor or contemporary who produced a body of work and established links with his or her peers. The Revista Estudos Feministas (REF), currently published at the Federal University at Santa Catarina, was launched in 1992, and over the years has occupied a prominent position as a pioneer and privileged publication for the promotion of feminist and gender studies in various subject areas in the country. Since 2001, its issues are available on Scielo, and this collection includes almost two dozen homages to the deceased in the form of obituaries, posthumous interviews or essays. We discuss how these articles present a biographical nature and characterize a constructed and claimed group memory in which dimensions of mourning and intellectual and institutional relations of an academic publication allow facing the pain of loss in the symbolic universe of the group.
\end{abstract}

Keywords: Obituary, Revista Estudos Feministas, Biography, Mourning. 


\section{Introdução}

Minha família anda longe

Reflete-se em minha vida,

mas não acontece nada: por mais que eu esteja lembrada,

ela se faz esquecida: não há comunicação!

Uns são nuvem, outros, lesma...

Vejo as asas, sinto os passos de meus anjos e palhaços, numa ambígua trajetória de que sou o espelho e a história.

Murmuro para mim mesma:

"É tudo imaginação!"

Mas sei que tudo é memória...

(Cecilia Meireles, Memória)

Expressão pesarosa, olhos baixos, gestual contido, fala tênue e pausada e, eventualmente, uso de óculos escuros são características comportamentais recorrentes na sociedade brasileira para a interação com alguém em situações de luto.

Aquela circunstância sempre indesejada de compartilhar uma dor tão íntima que se torna impossível de ser ponderada ou mesmo dividida de forma equitativa desperta o receio, de quem é próximo e de quem é distante, por não saber exatamente como se referir ou se comportar nessa situação específica. Desenvolve-se uma dinâmica postural e gestual que, em meio a diferentes níveis de empatia, busca garantir ao mesmo tempo uma aproximação $e$ um afastamento, de modo que o autocontrole e a discrição afirmam a presença e garantem um distanciamento capaz tanto de não incomodar como de aliviar as dificuldades de se expressar condolências.

Rezam as regras de etiqueta no Brasil urbano contemporâneo que, em uma situação de sofrimento, na qual um indivíduo não pode ausentar-se de todo, mas que também não quer invadir a privacidade de quem a 
experimenta, ele deve enviar um cartão, flores, ou algo semelhante. Através deles, deve expressar condolências ou solidariedade ao outro, e, mesmo assim, após alguns dias do fato ocorrido, ou quando houver uma cerimônia, como a missa de sétimo dia, por exemplo, fazer-se presente e, se próximo, cumprimentar o outro, na fila de condolências, com uma expressão contida, e ir embora, deixando ao outro a possibilidade de introjetar sua dor privadamente. $\mathrm{O}$ mesmo se aplica para quem sofre a perda. Cabe-lhe manter a dignidade e o controle de suas emoções, aceitando as condolências com um ar contido, e com uma ligeira indiferença no olhar (Koury, 2014:600).

O mesmo receio de não sabermos nos expressar e/ou nos comportar sentimos ao escolher um objeto de reflexão inusitado, os obituários de uma revista feminista de natureza acadêmica. Eles se apresentam como um desafio em diversos níveis: na amplitude e na fluidez da memória, na delicada dimensão emocional dos vínculos expressos pelas publicações, na diversidade política $e$ intelectual das personagens, na alteridade do grupo (mulheres feministas), entre outros, que antecipadamente parecem exigir desculpas pelas limitações dos resultados e das análises.

Os obituários, muito pouco estudados na tradição brasileira, nas revistas acadêmicas oscilam entre a narrativa rala que se atém ao cronológico e encadeia parágrafos padronizados que formam as simples "notícias de falecimento", e o texto elaborado, que busca delimitar um perfil de um predecessor ou igual que desfrutou de notoriedade e reconhecimento entre seus pares.

A Revista de Estudos Feministas (REF) é lançada em 1992, como publicação pioneira e privilegiada para a divulgação de estudos feministas e de gênero em diversas áreas disciplinares no país. $^{1}$

1 Atualmente é editada pelo Centro de Filosofia e Ciências Humanas (CFH) e pelo Centro de Comunicação e Expressão (CCE) da Universidade Federal de Santa Catarina. Desde 2001 os números da revista estão disponibilizados no Scielo, plataforma virtual de revistas acadêmicas mantidas pela Fapesp, e neste 
Esse conjunto de textos apresenta uma natureza biográfica $e$ caracteriza uma memória grupal construída e reivindicada, na qual as dimensões da vida $e$ da morte, do passado $e$ do futuro, da memória e do esquecimento buscam equacionar as demandas da dor e da perda no universo simbólico do grupo.

Nossa abordagem desse material se dá justamente pela sua dimensão biográfica, mediada pela situação de luto e dentro das relações intelectuais e institucionais de uma publicação acadêmica. A ausência, nesse caso, talvez imponha a obrigação grupal de garantir a lembrança e de proteger a memória, mas também de afirmar a presença do ausente no interior do grupo e de seus membros, tal qual na afirmação de Jacques Derrida, em seu texto de despedida sobre seu amigo Paul de Man: "A la muerte del otro nos damos a la memoria, y así a la interiorización, pues el otro, fuera de nosotros, ahora no es nada" (Derrida, 1998:44).

\section{A história de vida sobre os mortos}

O biografismo é uma forma de manifestação narrativa que envolve seleção, descrição e análise de uma trajetória individual, a partir de diversos enfoques e metodologias que se estendem desde o romance histórico até as biografias propriamente ditas, passando pelas narrativas pessoais (autobiografias, memórias $e$ testemunhos) e a literatura escolar, entre outras possibilidades. As práticas inseridas na escrita biográfica já foram definidas como a "história de uma só pessoa" $e$ ainda recebem reticências $e$ reservas de intelectuais de diferentes searas, como se falar de indivíduos fosse calar sobre assuntos mais urgentes e grandes injustiças.

Por outro lado, a biografia enquanto relato é o resultado de memórias coletivas, individuais e sociais que apresentam afirmações e negações, constantemente negociadas e processadas, $e$ que se corporificam a partir de relações particulares com 0

acervo encontram-se disponíveis quase duas dezenas de homenagens fúnebres, na forma de obituários, publicação de entrevistas póstumas ou ensaios. 
tempo e o espaço, que não são simplesmente atos de resgate, mas de reconstrução do passado a partir de referenciais atuais.

Nesse aspecto, uma forma de narrativa biográfica que é pouco estudada, mas que é de certo modo entendida como necessária e legítima são os obituários.

Esses textos, que se apresentam como histórias de vida que, contraditoriamente, são acionadas pela morte e que, enquanto gênero, se aproximam da biografia a ponto de dificilmente negarem seus referenciais clássicos, se justificam como o direito de antepassados ou grupos resistirem ao olvido, afirmarem suas identidades e reconhecerem um legado. ${ }^{2}$ Assim como na construção de uma biografia, exige-se no obituário, e em diferentes formas de luto através da narrativa, um diálogo com as distintas formas de controle simbólico do tempo e da individualização nas sociedades humanas.

Busca-se a tradução de uma experiência de duração através de estruturas imaginativas que relacionam uma vida com a cultura na qual o personagem se insere em uma "vida póstuma". Aquele que morre e aqueles que ainda vivem dialogam a partir das heranças e carências partilhadas, e a curiosidade quase voyeurista da biografia é substituída pela deferência e a afirmação de vínculos.

Discursos epidíticos como epitáfios, obituários e memoriais formam uma retórica fúnebre cujo objetivo é, indiferente à sua dimensão religiosa, integrar o morto ao seu novo lugar social, expressar o luto, a perda de um ente querido e, no caso em questão, a dimensão institucional e identitária que se afirma com força capaz de integrar o grupo em relação ao passado, ao presente e ao futuro.

A narrativa da vida, após a morte, expressa o desejo de ordenamento que é percebido como característica da

2 Santana (2011:55) identifica um amplo leque de manifestações de "gêneros textuais que realizam ações em uma circunstância fúnebre: epitáfio, nota de falecimento, nota de agradecimento, obituário, certidão de óbito, nênia, treno, epicédio, testamento, incelência, condolências, convite de missa, mementos ou santinhos de missas entre outros". 
modernidade ao manter na narração a dimensão de troca de experiências, pois segundo Benjamim (1994:207):

Durante o século XIX, a sociedade burguesa produziu, com as instituições higiênicas e sociais, privadas e públicas, um efeito colateral que inconscientemente talvez tivesse sido seu objetivo principal: permitir aos homens evitarem o espetáculo da morte. Morrer era antes um episódio público na vida do indivíduo, e seu caráter era altamente exemplar: recordem-se as imagens da Idade Média, nas quais o leito de morte se transforma num trono em direção ao qual se precipita o povo, através das portas escancaradas. Hoje a morte é cada vez mais expulsa do universo dos vivos. Antes não havia uma só casa e quase nenhum quarto em que não tivesse morrido alguém. (...) Ora, é no momento da morte que o saber $e$ a sabedoria do homem e sobretudo sua existência vivida - e é dessa substância que são feitas as histórias - assumem pela primeira vez uma forma transmissível.

Tal narrativa, no entanto, se desenvolve a partir de uma nova condição do indivíduo, na ruptura da morte, e a forma de singularização do indivíduo a partir de um nome próprio, pessoal e privado se mostra como uma distinção do sujeito social. A contratualidade do registro civil, por sua vez, agrega

uma identidade social constituinte e duradoura que garante a identidade do indivíduo biológico em todos os campos possíveis nos quais ele intervém como agente, isto é, em todas as suas histórias de vida possíveis (Bourdieu, 1996:78).

O nome próprio é a forma por excelência da imposição arbitrária feita pelos ritos institucionais: a nominação e a classificação introduzem divisões nítidas, absolutas, indiferenciadas nas particularidades circunstanciais e nos acidentes individuais, no fluxo e na fluidez das realidades biológicas e sociais (Bourdieu, 1996). 
Se o nome próprio é para o cidadão a expressão de sua identidade, embora essa dimensão exista como algo universal, em relação ao mundo acadêmico esse nome se projeta como guardião de uma obra, que construída social e historicamente se mostra como reflexo de realizações, vínculos, simpatias, antipatias, apreciações $e$ indiferenças em um espaço relacional bastante delimitado.

Fabre retoma a expressão "fazer da vida uma obra" $e$ problematiza como se estabelecer gradientes para se medir uma existência:

A obra é o que se faz, o que se cria e, ao mesmo tempo, o que se faz da vida e, portanto, o que se é. Mas será que podemos pensar da mesma maneira, ou seja, com as mesmas categorias, o que se é e o se faz? De igual modo, temos critérios que fazem com que uma vida possa ou não ser qualificada como uma obra: o que é uma vida bem sucedida e que tipo de sucesso exige a ideia de obra? (Fabre, 2011:348).

E o texto de um obituário, um necrológio, é uma forma de afirmar essa obra e a partir dela identificar no interior de determinado grupo as dívidas do vivido $e$ as promessas do desejado.

Textos dessa natureza, no interior de uma publicação acadêmica, enfrentam esse desafio, pois ao mesmo tempo que se destinam a apresentar a trajetória de um notável ou de um membro do grupo, são normatizados como ethos ${ }^{3}$ pelas exigências

3 Ethos utilizado aqui, de forma ampla, como o define a Análise do Discurso, ou seja, enquanto comportamento verbal e não verbal dos envolvidos em um processo de interação social e que se traduzem como modos de enunciação (maneiras de dizer e de se apresentar), a partir de indícios de tom, caráter e corporalidade. Assim, o ethos se projeta a partir de toda troca verbal, tanto oral como escrita, $e$ na qual a manifestação discursiva possui uma especificidade que desenha uma imagem de si, que será (ou não) incorporada pelo auditório. (Fairclough, 2001; Amoussy, 2005; Maingueneau, 2008) O conceito também é utilizado nas ciências sociais, sendo apropriado por pensadores como Alfred Kroeber, Clifford Geertz, e Robert Merton. 
sociais do luto $e$ obrigações intelectuais $e$ políticas do pertencimento.

Em termos literários ou discursivos, Santana (2011) diferencia os discursos sobre a morte na sociedade ocidental: o epitáfio, com sua origem etimológica ("sobre o túmulo"), apresenta uma dimensão espacial na qual a morte é um tópico e o túmulo uma materialidade; as elegias fúnebres (a nênia, o epicédio $e$ o treno) têm suas origens na literatura greco-romana, como formas de um canto triste que, dotado de caráter laudatório, moralizante, exortativo e sentencioso, era muitas vezes recitado em público; o obituário, por sua vez, originado nos Oitocentos, divulga ao público em geral a morte de membros da sociedade, funciona como estratégia de superação do luto pela perda de um ente querido e reforça a importância do papel social dos falecidos; $e$ os anúncios fúnebres (convites, agradecimentos, notas de falecimento $e$ de pesar) possuem a finalidade prática de organização dos funerais $e$ na criação de outros eventos relacionados ao óbito, envolvendo tanto parentes como amigos e instituições a que pertencia o morto.

Tanto o obituário como os anúncios fúnebres encontram na imprensa o seu local privilegiado de manifestação, embora na perspectiva jornalística essas narrativas fúnebres tenham características bastante diferentes. Desse modo, necrológio, nota de falecimento e obituário significariam respectivamente um texto laudatório, outro meramente informativo (e pago) e, por último, o texto baseado em virtudes, realizações e méritos daquele que faleceu, destinado a "justificação seletiva de determinados indivíduos na morte" (Fowler, 2007:41).

Desde 2007, inspirada nos textos de Alden Whitman para o jornal New York Times, a Folha de S. Paulo criou uma seção específica do jornal com o título de obituário, em que se pretende, após a morte de um indivíduo, expor de forma literária, isenta de críticas, detalhes e minúcias convertidos em aspectos curiosos, importantes e atraentes de pessoas conhecidas ou não pela maioria dos leitores (Suzuki Jr., 2008; Scarpin, 2008). 
Com certeza não é essa a dimensão dos textos de luto da $R E F$, pois embora se faça presente a dor da perda, há nesses textos elementos particulares pela forma de a delimitação das personagens retratadas (militantes $e$ intelectuais ligadas ao feminismo) e a perspectiva de trajetória enquanto processo de afirmação de uma obra ou legado. A narrativa biográfica do obituário é, entre outros aspectos, um processo de construção identitária que se relaciona diretamente com um ethos, ligado aos campos de atuação do personagem, que de forma argumentativa estrutura um perfil. Santana (2011) identifica referências recorrentes nos obituários a partir de dois eixos discursivos, um que trata da morte com a identificação (pelo nome $e$ características sociais do personagem) e as circunstâncias (data, lugar, idade, causa), e outro que trata da vida, com a história (pelas origens e realizações) e família (particularmente cônjuge $e$ filhos).

A natureza acadêmica e feminista dos textos aqui abordados anula alguns dos referenciais típicos e introduz outros, com ênfase nas realizações e a substituição da dimensão familiar pela de vínculo ou herança intelectual, de modo tal que aos objetivos tradicionais de notificação e de elogio público se soma o da uma representação acerca do impacto provocado pela morte de alguém que ocupava posição de destaque no grupo ou instituição social ao qual se vinculava.

Dessa maneira, ao enfatizar a dimensão grupal $e$ institucional,

o obituário ratifica o propósito retórico dos obituários que não é consolar os mais próximos ao falecido nem manter um sentido de continuidade ou perpetuação em face de uma perda, mas atribuir ao falecido uma identidade e valor social, por meio da intensificação dos mais variados papéis desempenhados no grupo social em que se insere o morto (...), celebrando o valor do cidadão como indivíduo. $\mathrm{Ou}$ seja, apresenta-se como "uma certa identidade pública do falecido" (Santana, 2011:195). 


\section{A Revista de Estudos Feministas e seus lutos}

Surgida em 1992, no Rio de Janeiro, com apoio da Fundação Ford, a $R E F$ apresentava uma proposta ambiciosa, pois nascia com um projeto gráfico diferenciado, conteúdo qualificado e um encarte com a tradução dos artigos em inglês, buscando evitar a sua institucionalização através do rodízio de editoras e de instituições-sedes da publicação (o que efetivamente ocorreu entre 1992 e 1998, período no qual foi editada no Rio de Janeiro) (Lago, 2013).

Lena Lavinas, sua primeira editora, explica o encarte inserido na revista contendo a tradução de artigos em inglês, com a intenção de dar divulgação internacional à produção brasileira no campo dos estudos de gênero. Esse encarte, que encarecia a edição da revista, deixou de ser publicado quando a REF fez a viagem do Rio de Janeiro para Florianópolis onde passou a ser editada em parceria entre os centros de Filosofia e Ciências Humanas, e Comunicação e Expressão ( $\mathrm{CFH} / \mathrm{CCE}$ ) da UFSC, por um coletivo de pesquisadoras que foi se ampliando para outros centros e instituições, como a Universidade do Estado de Santa Catarina (UDESC). Na mudança para Florianópolis, a REF foi institucionalizada, distanciando-se assim das intenções iniciais de suas idealizadoras (Lago, 2013:644).

A transferência da revista para Florianópolis, a partir de proposição de Luzinete Minella, também significou uma reestruturação editorial, com a criação de diferentes editorias, compostas por mais de uma pessoa e encarregadas de suas distintas seções (coordenação editorial, editorias de dossiês, de entrevistas, debates, resenhas, entre outras).

A $R E F$ se projeta como um espaço de confluência entre militância e reflexão, o que pode ser percebido em suas diferentes seções.

Na trajetória da REF, esse diálogo e essas articulações entre a academia e a militância, passaram por diferentes 
momentos e assumiram diferentes formas. A própria escolha pelo nome Estudos Feministas para a revista é um indicativo do desafio que o coletivo de mulheres fundador da revista assumia a partir daquele momento. Certamente o dossiê é a seção mais representativa dessa tensão, é onde esses fluxos e refluxos do diálogo entre ativismo e produção acadêmica apresentam mais visibilidade. Esta questão está presente na revista como um todo e é constitutiva do próprio campo dos estudos feministas, não apenas pelas trajetórias de muitas mulheres, hoje professoras $e$ pesquisadoras, que foram protagonistas dos movimentos $e$ das lutas que antecederam e ajudaram a formar os estudos feministas e de gênero, mas também pelas implicações políticas e epistemológicas da própria existência dos estudos feministas (Maluf, 2004:235).

Assim, conforme uma autodefinição no Scielo ${ }^{4}$,

a revista vem contribuindo para a consolidação do campo dos estudos feministas e de gênero no Brasil, tornando-se uma referência obrigatória para pesquisadoras $e$ pesquisadores das mais variadas áreas disciplinares. ${ }^{5}$

Encontram-se disponibilizados no Scielo os números publicados de 2001 em diante, quando as edições eram semestrais. A a estrutura básica da revista apresenta-se composta por artigos, traduções de artigos de cunho teórico publicados em outros idiomas, exceto o português e espanhol, entrevistas com pesquisadoras de renome no campo dos estudos feministas, dossiês temáticos sobre assuntos atuais e de relevância para

\footnotetext{
${ }^{4}$ [http://www.scielo.br/revistas/ref/paboutj.htm]

5 Em sua página na plataforma Scielo, a publicação, que é classificada como Qualis A1 pela CAPES na área de História, Letras/Linguística, Antropologia, Filosofia e Interdisciplinar, identifica como sua missão: "Divulgar a vasta produção de conhecimento no campo dos estudos feministas e de gênero, buscando dar subsídios aos debates teóricos nessa área, bem como instrumentos analíticos que possam contribuir às práticas dos movimentos de mulheres".
} 
pesquisadoras/es e ativistas, e resenhas. Uma seção específica de entrevistas, intitulada Ponto de Vista ${ }^{6}$, é usada eventualmente como espaço de homenagem póstuma. ${ }^{7}$ Entre as dinâmicas de lembrança/reconhecimento e esquecimento/negação de "ancestrais" e "descobertas", os obituários podem ser pensados, no caso da $R E F$, como uma forma de patrimonialização da memória dos personagens, particularmente quanto mais próximos se situem do grupo, e também de afirmação de uma linhagem política e intelectual do feminismo.

Não são heroínas, matriarcas ou mártires, são feministas

É necessário perceber que a dual presença das perspectivas militante e acadêmica da revista significa de forma clara um posicionamento dentro de disputas sobre projetos, objetos $e$ identidades em que "feminista" disputa espaço com "de mulheres" e com "de questões ou políticas de gênero", pois como aponta Grossi (2004:217) em evento para celebrar os dez anos da revista:

Mesmo me colocando do lado da ideia de que há um campo, tenho dúvidas sobre a denominação de estudos feministas como um rótulo englobante dos estudos que são feitos hoje neste lugar. Em sessão anterior deste evento pude acompanhar "ao vivo" a tensão entre diferentes posições políticas sobre o lugar dos estudos acadêmicos no

\footnotetext{
6 "Desde o vol. 6, n 1/1998, quando Joan Wallach Scott foi entrevistada por Miriam Grossi, Maria Luiza Heilborn e Carmen Rial, e se iniciou o processo de institucionalização da entrevista como carro-chefe da seção Ponto de Vista da $\mathrm{REF}$, foram publicadas, até o número atual da revista, 37 entrevistas. Isso sem contar a publicação, no Dossiê Leila Diniz do vol. 2, n 2/1994 da REF, da 'Entrevista de toda uma geração', concedida por Leila Diniz ao extinto jornal $O$ Pasquim" (Lago, 2013:646).

7 Para Heloneida Studart (vol. 16, $n^{\circ}$ 1/2008) e Heleieth Saffioti (vol. 19, $n^{\circ}$ $1 / 2011$ ). As homenagens póstumas surgem desde o primeiro número da revista, em que se apresenta, entre os diversos artigos, "um texto de Heleieth Saffioti sobre Bete Lobo, importante teórica feminista brasileira que havia morrido no início dos anos 90" (Grossi, 2004:214).
} 
campo militante e vice-versa. Suely Almeida (professora de História da UFF) lembrava dos embates que havia presenciado em diferentes encontros da REDEFEM entre feministas e estudiosas de gênero. Ana Alice Costa (professora de Ciência Política da UFBA) fez uma intervenção classificando estas últimas como generólogas, termo que também escutei em outras ocasiões, usado de forma pejorativa e fundamentalista por algumas colegas como categoria acusatória de despolitização feminista. Impossível continuar meu texto sem repensar este ponto que parece ainda ser nevrálgico das relações de poder, hierarquia e classificação no interior do campo no qual estamos trabalhando.

Embora Grossi (2004:218), afirmando a ambição de respeito à diferença e à pluralidade, também sublinhe que "tanto nos editoriais, como nos folders e outros materiais de divulgação da revista, sempre usamos as duas categorias - feministas e de gênero - para designar o campo de abrangência da REF".

No período aqui abordado (2001-2014), somente em 2004 (no vol. 12, $\mathrm{n}^{\circ} 1 / 2004$, mesmo ano em que a publicação se torna quadrimestral), é publicado o primeiro texto em seção específica In Memorian - para manifestar o luto por uma intelectual e/ou militante feminista.

A homenagem é à escritora e teórica cultural norteamericana, de origem mexicana, Gloria Evangelina Anzaldúa (1942-2004), que é identificada como uma das "primeiras autoras americanas de origem mexicana assumidamente lésbicas" e que "desempenhou um papel de grande relevância na redefinição de identidades chicanas, lésbicas e queer" (Costa, 2004:13), despontando como representante da defesa do multiculturalismo e de um feminismo de inclusão.

A reprodução de uma página que circulou pela internet como necrológio da autora e um curto texto, de uma página, de Cláudia de Lima Costa, intitulado "O Silêncio da Tradução" busca render homenagem, afirmar a memória e despertar o interesse pela personagem e sua obra. O texto de Costa (2004) ao mesmo 
tempo que afirma a dimensão seminal de obras da autora (que "veiculavam em suas formulações epistemológicas as ideias de fronteira $e$ de hibridismo inicialmente articuladas com tanta criatividade" e ainda "representam a elaboração fundacional de uma poética e política do hibridismo cultural") lamenta a ausência de traduções da autora no país, identificando a dificuldade de acesso aos textos como reflexo de uma geopolítica da tradução (que exclui "eixos da diferença") e que resulta em uma perda para "nós - o feminismo".

Portanto, a obra de Anzaldúa seria um patrimônio a ser afirmado pelo amplo leque de discursos que identificam as lutas pelas questões feministas e de gênero. Ainda como reconhecimento do legado da autora, a revista publica no ano seguinte (vol. 13, $n^{\circ} 3 / 2005$ ) uma tradução de um de seus mais importantes artigos ("La conciencia de la mestiza: rumo a uma nova consciência"), na seção Debates.

O próximo obituário analisado, é publicado na seção In Memorian, em 2006 (vol. 14, $\mathrm{n}^{\circ}$ 1/2006) em um texto de sete páginas escrito por Ana Rita Fonteles Duarte sobre a feminista norte-americana Betty Friedan. Com o subtítulo "morre a feminista que estremeceu a América", aborda a trajetória da autora do polêmico Mística feminina (1963), best-seller que discutindo a identidade feminina $e$ a construção da imagem da mulher como dona de casa perfeita, mãe e esposa se tornou referência dentro da chamada "segunda onda feminista".

O texto de Duarte (2006) apresenta as reflexões de Betty Friedan como consequência da experiência da autora enquanto mulher norte-americana que, nas décadas de 50 e 60, sofria com um "problema mal formulado" ou "mal sem nome", característico de uma geração de mulheres envolvidas com

dificuldades com os filhos, o casamento, a casa, a comunidade. Segundo ela, os ecos do problema podiam ser ouvidos em dormitórios universitários, enfermarias de maternidades, reuniões de pais e mestres, almoços da Liga das Mulheres Votantes, coquetéis, carros à espera de trens. 
O problema ultrapassava classes sociais, idades, credos $e$ etnias (Duarte, 2006:287).

O sucesso do livro a partir do reconhecimento de suas leitoras do processo de opressão estabelecido pela idealização de uma mulher que existe somente em função de seu papel de esposa e mãe permitiu a fundação, pela autora, em 1966, da organização feminista, a Organização Nacional de Mulheres (National Organization for Women - NOW), que obteve significativa relevância nos debates públicos nos Estados Unidos.

Duarte (2006:289) identifica nas bandeiras e práticas do grupo méritos, como a denúncia do sexismo e do consumismo, assim como a reivindicação de igualdade ${ }^{8}$, e deméritos, como a incapacidade de crítica às estruturas sociais e a exclusão social e racial em seu interior.

O texto ainda descreve, de forma minuciosa, o impacto da passagem da feminista pelo Brasil, no início da década de 70, a convite de Rose Maria Muraro - na época na Editora Vozes, e a avaliação dessa visita pela jornalista e psicanalista Carmen da Silva, que criticou distorções de afirmações de Friedman pela imprensa local, na seção "A arte de ser mulher", que mantinha na revista Claudia. O balanço final da obra da personagem reafirma a importância de Mística feminina, faz menção a outros livros da autora, e aponta seu afastamento, no final da vida, da questão feminista e a tensão com as feministas radicais que lhe acusavam de traição à causa.

O texto, com extensão significativa - sete páginas em contraste com duas do obituário anterior -, reflete a repercussão da obra de Betty Friedan, que se projetou para além do reconhecimento restrito da militância feminista e se afirmou como ponto de referência obrigatório sobre o papel da mulher na

8 Enquanto eram descritas como "frustradas, neuróticas, homossexuais, megeras ressentidas, espumando de ódio contra o sexo masculino" as feministas do NOW defendiam quatro conquistas: "oportunidades iguais de acesso ao trabalho e à instrução, paridade de salários para tarefas iguais, legalização do aborto, abertura de creches em regime de tempo integral em todo o país" (Duarte, 2006:290). 
sociedade contemporânea. Chama a atenção a nomeação de importantes feministas da década de 70 no Brasil, como Rose Maria Muraro e Carmen da Silva, em seus vínculos com Betty Friedman durante sua estada no país, não só como fidelidade à descrição dos fatos, mas também como reconhecimento de um campo e de seus agentes no período.

$\mathrm{O}$ ano de 2008 foi particularmente difícil para o feminismo acadêmico-militante da $R E F$, pois a revista teve publicadas três homenagens fúnebres nesse período: à escritora $e$ militante Heloneida Studart (vol 16, no 1/2008), à socióloga e professora da Unicamp, Maria Isabel Baltar da Rocha Rodrigues (vol 16, $\mathrm{n}^{\circ}$ $3 / 2008$ ), e a nota de falecimento da pesquisadora cubana Nara Araújo (vol. 16, n 3/2008). ${ }^{9}$

Heloneida Studart é homenageada de duas formas na mesma edição, com a publicação do artigo "Uma escritora feminista: fragmentos de uma vida", de autoria de Cecília Cunha, com seis páginas, e em uma seção denominada Homenagem a Heloneida Studart, com a entrevista realizada por Roselane Neckel, com o título “'Entra, menino', 'Xô, galinha' e 'Sim, senhor!': entrevista com Heloneida Studart", com cinco páginas.

Maria Isabel Baltar da Rocha Rodrigues, por sua vez, é o personagem de um perfil, com o seu nome e o subtítulo "fazendo da ciência uma política", ocupando três páginas em seção intitulada Homenagem, escrito por Luzinete Simões Minella.

O texto sobre Maria Isabel Baltar da Rocha Rodrigues iniciase identificando a filiação acadêmica da personagem, socióloga, docente e pesquisadora da Unicamp com vínculos com a Associação Brasileira de Estudos Populacionais - ABEP, e com o Núcleo de Estudos de População - NEPO, da Unicamp, e o Instituto Patrícia Galvão, e sua prática militante de "feminista

9 A nota de falecimento informa as datas de nascimento e morte da personagem (1945-2009), envolvimento e colaboração com o movimento feminista $e$ universidades brasileiras $e$ afirma que seu "entusiasmo $e$ amor à vida $e$ à amizade não serão esquecidos, assim como sua competência intelectual e o generoso empenho para fortalecer essa área de estudos que apenas se iniciava entre nós" (REF, 2008:1138). 
comprometida com várias causas relacionadas aos direitos reprodutivos e à saúde das mulheres". Há menção ainda a alguns traços de personalidade da intelectual feminista, no que se refere ao "seu jeito sereno, competente e humano de fazer da ciência uma política" (Minella, 2008:1135). E é apresentado um curriculum vitae acadêmico, da graduação à profissionalização como professora e pesquisadora, além de uma descrição de sua participação em grupos feministas ${ }^{10} e$ das manifestações de pesar em diversos grupos e instituições. ${ }^{11}$

O texto parece refletir o impacto da morte, pela forma disruptiva que teve - um acidente de trânsito - na ênfase da narrativa na interrupção na construção de uma obra $e$ no vazio institucional por ela provocada. Tal qual o subtítulo utilizado, que enfatiza a aproximação entre ciência e política, não há a dimensão subjetiva (na ausência de referências sobre origens, nascimento, vínculos familiares e afetivos), nem caráter laudatório $e$ sentencioso, mas uma escrita objetivada que ao mesmo tempo divulga a perda ao público em geral e reforça a importância do papel social da falecida em sua dimensão acadêmico-militante. Essa perspectiva, de relativo afastamento, não é a mesma adotada

\footnotetext{
10 "Sua capacidade de intenso diálogo com os movimentos feministas fica evidente nas suas participações em importantes organizações: entre 2001 e 2002 foi secretária-executiva da Rede Feminista de Saúde, Direitos Sexuais e Direitos Reprodutivos (Rede Feminista de Saúde), tendo integrado o seu Conselho Diretor. A partir de 2003, participou também do Conselho Consultivo da Red de Salud de las Mujeres Latinoamericanas y del Caribe (RSMALC) e da organização Católicas pelo Direito de Decidir. Além disso, entre 2004 e 2006, fez parte do Comitê Assessor Nacional da Comissão Intergovernamental de Saúde Sexual e Reprodutiva do Mercosul do Ministério da Saúde" (Minella, 2008:1036).

11 "Nos dias posteriores ao seu falecimento, testemunhando sua significativa participação nos debates políticos, inúmeras instituições de ensino e pesquisa manifestaram o seu pesar e várias organizações a homenagearam em seus sites, como por exemplo, além do Instituto Patrícia Galvão, a Rede Feminista de Saúde, o Conselho Nacional dos Direitos da Mulher, a organização Católicas pelo Direito de Decidir, a Comissão de Cidadania e Reprodução, entre outras" (Minella, 2008:1037).
} 
em relação a Heloneida Studart, tanto no artigo, quanto na entrevista já citados.

O perfil sobre essa escritora, intitulado Uma escritora feminista: fragmentos de uma vida, de autoria de Cecília Cunha, inicia-se convidando o leitor a um contato com as dimensões subjetivas da personagem. Foram reproduzidos trechos de alguns de seus escritos dotados de uma dimensão autobiográfica e que falavam da infância no Ceará, da escritora que nascera em 1925, que era a morena em uma família de "loiras lindas" e que, nas palavras do pai, era a mais linda por ser a mais inteligente já que com o passar do tempo as irmãs seriam menos linda e ela continuaria inteligente.

A narrativa marca uma trajetória bastante rica e revela uma pequena dose de determinismo, pois a escritora e a feminista parecem já existir na infância, e não fossem justificações das memórias da infância de uma mulher já feita e consagrada:

Aprendeu as primeiras letras com uma empregada, chamada pelas suas tias mais velhas de "a negra", uma filha de índios que a alfabetizou clandestinamente. Desde cedo teve o incentivo de seu pai, que possuía uma biblioteca com mais de dois mil livros (...). O gosto pelo conhecimento era a sua prioridade de vida. Seguindo os costumes das famílias abastadas, passa a freqüentar o Colégio Imaculada Conceição de Fortaleza. Em meio ao ambiente de recato e muita oração, a pequena Heloneida, aos nove anos, já começa a escrever as suas histórias. Colaborou com crônicas no jornal $O$ Nordeste, porta-voz oficioso da Igreja Católica, causando polêmica entre amigos e familiares. Recorda: "Uma mulher pública! Não vai achar um bom partido!". Também estudou escondida da família para um concurso no Ministério da Fazenda; aprovada, tornou-se um desgosto para a sua mãe, por ser "a mulher que trabalha fora". Somando-se a isso, foi participante da Casa de Juvenal Galeno, da chamada Ala Feminina, organizada por Henriqueta Galeno. Essa organização tinha como propósito estimular a atuação das mulheres nas letras cearenses. E como a capital da República era o centro 
cultural do país, em 1949, Heloneida muda-se para o Rio de Janeiro, e passa a cursar Ciências Sociais na Universidade Federal do Rio de Janeiro (Cunha, 2008:272).

Desfilam na narrativa as conquistas e os percalços da escritora, jornalista e teatróloga, com a sua militância política $e$ feminista, a perseguição pela ditatura civil-militar, a proximidade com Rose Marie Muraro, Branca Moreira Alves e Moema Toscano (que juntas fundaram a primeira entidade feminista no Brasil: o Centro da Mulher Brasileira - CMB), e a construção de uma obra literária em paralelo a uma longa carreira como deputada estadual, que começou no MDB, depois $\mathrm{PMDB}$, pelo PSDB e, finalmente, pelo $\mathrm{PT}^{12}$ (Cunha, 2008:272-274).

A trajetória pública, intensa e frutífera, não obscurece a dimensão pessoal e privada na narrativa:

Heloneida Studart teve como companheiro de sua vida o engenheiro têxtil e administrador de empresas Franz Orban. Jornalista, radialista, escritora, feminista, ex-deputada, mãe (seis filhos do sexo masculino e uma filha adotiva), ela faleceu, aos 82 anos, vítima de parada cardíaca, na manhã do dia 3 de dezembro de 2007 no Rio de Janeiro (Cunha, 2008:275).

“'Entra, menino', 'Xô, galinha' e 'Sim, senhor!': entrevista com Heloneida Studart" foi realizada em 2005 por Roselane Neckel, como parte de um projeto de pesquisa sobre as origens do feminismo no país, e permite, segundo a autora, reafirmar a forma

12 "Durante a sua atuação como parlamentar, Heloneida exerceu vários cargos importantes (...) [e] sua atuação no Legislativo se destacou por criar leis que vieram a beneficiar mulheres e trabalhadoras, tais como a lei que garantiu o exame de DNA para mães de baixa renda; a lei que obriga as unidades públicas e conveniadas de saúde a realizar cirurgia reconstrutiva de mama em mulheres que sofreram mutilações decorrentes de câncer; a lei que garantiu a distribuição gratuita de medicamentos para tratamento e monitoramento da diabetes; e a que obriga o serviço público a conceder um dia de licença por ano a funcionários com 40 anos ou mais para exame preventivo de câncer" (Cunha, 2008:274). 
como as "histórias de vida" da entrevistada constituíram sua forma de "ser feminista". A entrevista tem uma forma coloquial e é uma "história de vida" no sentido clássico das pesquisas que se utilizam da história oral, na qual a feminista, na época deputada, narra sua trajetória e, em meio a dois ou três casos pitorescos, faz um rápido balanço do feminismo.

Outra personagem reverenciada de duas formas é Heleieth Saffioti (1934-2010), que recebeu uma nota de falecimento (vol. 18, n 3/2010) e a publicação de uma longa entrevista, de 23 páginas, realizada por Juliana Cavilha Mendes e Simone Becker (vol. 19, $\mathrm{n}^{\circ}$ $1 / 2011)^{13}$

A nota de falecimento segue padrão clássico, com informações biográficas básicas e que, sem dimensão laudatória, se apresenta como um texto meramente informativo sobre a vida e obra da socióloga, que fora autora pioneira sobre estudos feministas no país, fez parte do conselho consultivo da Revista Estudos Feministas desde seu primeiro número, além de ser autora de um artigo no número zero da revista, em 1992.

A entrevista, por sua vez, é estruturada em duas partes, como se apresentasse de forma quase dicotômica vida $e$ militância, memória e reflexão, em que a primeira se chama "Trajetória de uma feminista", e a segunda, "Gênero, violência e outros temas". ${ }^{14}$ Embora a primeira pergunta seja dirigida a aspectos intelectuais e políticos, indagando sobre a formação educacional e a relação dessa trajetória com o feminismo, a

\footnotetext{
${ }^{13}$ Na página 141, antes da entrevista, Luzinete Simões Minella esclarece: "Assim, agradecemos a Zahidé Muzart, da Editora Mulheres, e a Miriam Grossi e Rozeli Porto, organizadoras da coletânea Depoimentos: trinta anos de pesquisas feministas brasileiras sobre violência, a oportunidade de reeditarmos a entrevista de Heleith Saffioti constante daquela publicação. A entrevista foi realizada em julho de 2004, pelas então doutorandas do Programa de Pós-Graduação em Antropologia Social Juliana Cavilla Mendes e Simone Becker, como parte do projeto de pesquisa "Mapeamento nacional de pesquisas e publicações sobre violências contra mulheres", desenvolvido no Núcleo de Identidades de Gênero e Subjetividades (NIGS/UFSC), sob a coordenação de Miriam Pillar Grossi".

${ }^{14} \mathrm{O}$ caráter acadêmico também se faz presente pela existência de bibliografia após a entrevista.
} 
entrevistada faz um breve relato de sua infância e adolescência, inclusive com referências sobre o incesto ${ }^{15}$ e o assédio ${ }^{16}$, e da idade adulta, sobre a qual, com uma sinceridade incomum, oferece algumas deliciosas confissões e considerações. ${ }^{17} \mathrm{O}$ relato de Heleieth Saffioti expõe e reflete tanto sobre sua vida pessoal $e$ profissional quanto sobre o período no qual se insere a sua trajetória, de forma coerente e agradável.

Algo importante, dentro de uma entrevista longa como essa, é o balanço que a socióloga faz de seu trabalho mais conhecido, o livro $A$ mulher na sociedade de classes: mito e realidade (1969), afirmando endossar sua tese central ao se referir ao Modo de Produção Capitalista (MPC), em contraste com críticas advindas do

15 "Até que, com quase 13 anos, fui para a casa de uma tia, em Avaré, também no interior de São Paulo, que era casada, mas não tinha filhos. Acontece que ela ficou doente, um mês depois de eu ir morar com ela. Como não ficava bem permanecer sozinha com o marido dela, levaram-me para Itapetininga, onde eu tinha outro tio paterno, que era professor na Escola Agrícola. Mais adiante, estudei o abuso incestuoso, tendo aprendido que, muitas vezes, 'o inimigo mora em casa'. Hoje, conhecendo esse sério problema, vinculo a atitude de minhas tias paternas, de não me deixarem em Avaré, com o marido de minha tia, à maior experiência delas, se comparada à minha" (Mendes; Becker, 2011:143).

16 "[Aos 14 anos, morando na casa de parentes em São Paulo] fazia todo o trabalho da casa, estudava à noite, chegava de volta a casa, sozinha, após a meia noite. Tinha que descer uma ladeira, e quantas não foram as vezes em que a desci voando, porque me haviam assediado no ônibus. Uma moça de 14 anos, embora de uniforme, era considerada uma menina sozinha. Então, colocavam a mão na minha perna, simulavam esbarrar em meus seios. Era um 'assédio sexual' bastante ameaçador para quem enfrentava, pela primeira vez, a grande cidade. Alguns desses homens chegavam a descer do ônibus e ir atrás de mim" (Mendes; Becker, 2011:144).

${ }^{17}$ Como chamar as tias com quem morou aos 14 anos, em São Paulo, de tiasbruxas, afirmar que entre seus catorze tios - sete mulheres e sete homens - a longevidade das mulheres se fosse regra e permitisse um mundo totalmente feminino criaria uma sociedade de uma "chatice infinita!", a descrição do pai como alguém que "trabalhava quando queria" e da mãe como "provedora" $e$ "disciplinadora", ou ainda, sobre si mesma, como alguém que é "dura apenas na aparência" e que na verdade se revela "uma mulher ultrassensível, uma mãezona, com aquele coração no qual sempre cabe mais um" (Mendes; Becker, 2011:145). 
trabalho de Cristina Bruschini ${ }^{18}$, Mulher e trabalho: estudo de algumas profissóes de nivel superior (1977), por considerar que os dois trabalhos enfocam realidades distintas (o dela, atividades ainda não completamente incorporadas pelo MPC, o de Bruschini, ao contrário, com o perfil de professoras, enfermeiras $e$ engenheiras), e a confissão de que a escrita hermética - obrigação de ofício na época - seria hoje substituída por uma linguagem mais simples e capaz de ser compreendida por todas as mulheres (Mendes; Becker, 2011).

E como a referendar a própria proposta da $R E F$, quando indagada sobre a relação entre academia e militância feminista, afirma:

Considero que há militantes que são exclusivamente militantes. Em geral, são pessoas que não leem, não discutem. (...) Não me agrada nada, nada, esta divisão: feminismo acadêmico versus feminismo militante. No Brasil, a academia abriu, sem resistência digna de nota, suas portas à temática de gênero e, ademais, há um trânsito fácil entre acadêmicas e militantes, sem contar o fato de que muitas militantes são também acadêmicas ou, pelo menos, leem e discutem suas leituras, não sendo, por conseguinte, apenas militantes (Mendes; Becker, 2011:155-156).

Em 2011, dois anúncios de luto, a nota de falecimento de Karin Ellen Von Smigay (1948-2011), professora aposentada do Departamento de Psicologia da UFMG (vol. 19, no 1/2011) e uma homenagem a Maria Lúcia de Barros Mott, com o subtítulo "pesquisadora militante" (vol. 19, n 2/2011), escrito por Carmen Susana Tornquist e contando com três páginas. ${ }^{19}$

\footnotetext{
${ }^{18}$ A também socióloga Cristina Bruschini (1944-2012) é homenageada pela revista com um obituário escrito por Luzinete Simões Minella (vol. 20, $\mathrm{n}^{\circ}$ 1/2012), analisado mais adiante.

${ }^{19}$ Maria Lúcia de Barros Mott (de Melo Souza, 1948-2011) também teve um obituário publicado pelo jornal Folha de S. Paulo, no modelo que o jornal busca consagrar, entre o pitoresco e o lírico: "A tese de doutorado defendida por Maria Lúcia de Barros Mott na Faculdade de História da USP, no anos 90, resgatava a
} 
A nota de falecimento é típica, exceto pela referencia à cremação da personagem $e$ a realização de um ritual de despedida em sua Pousada d'Oleo de Guignard (em Tiradentes, MG). A homenagem se inicia com uma reflexão sobre os recentes lutos na revista:

Vivenciando recentemente a perda de familiares de amigas $e$ a perda de amigas queridas, temos ficado abaladas com a necessidade que se tem repetido de elaborar essas notas de falecimento nos últimos números da revista. Estamos perdendo também nossas amigas/companheiras feministas $e$, por mais que saibamos que a morte faz parte e é consequência natural da vida, estamos conscientes também de que sua elaboração no luto é um trabalho, como definiu Freud, um trabalho individual penoso e com tempo próprio. Na REF a perda de Maria Lúcia Mott foi sofrida de forma coletiva (Tornquist, 2011:634).

O texto da homenagem assume a dor da perda que é compartilhada pelo grupo, a partir da leitura de entrevista dada pela personagem em 2005, e que às autoras "causou muita comoção" e as fez sentirem-se "de certa forma identificada(s)", entre outras coisas, por tratar-se de alguém que também se definia, em suas próprias palavras, a partir de uma dupla

trajetória da primeira parteira diplomada no Brasil: Madame Durocher. Aproveitando-se da pesquisa feita para esse trabalho, Cuca, como era chamada, resolveu escrever ficção. Em meados dos anos 90, 'O Romance de Ana Durocher' saiu pela editora Siciliano. Publicar livros era coisa comum na família. Sua mãe, Odette de Barros Mott, foi uma conhecida autora de mais de 60 obras de literatura infantojuvenil. A própria Cuca chegou a se aventurar escrevendo para crianças. (...) Cuca também se envolveu com pintura (foi uma das precursoras da pintura na Praça da República nos anos 60) e com esculturas em barro. O marido, o também historiador José Inácio de Melo Souza, conta que a história foi a grande paixão da vida da mulher. Ela gostaria de ter finalizado seu último trabalho, ao qual se dedicou por quatro anos: um livro sobre a história dos hospitais de São Paulo. Não teve tempo. Morreu no domingo, aos 62, devido a um câncer de pulmão. Deixa uma filha". 
dimensão: "Sempre via a pesquisa como uma forma de militância política” (Lago; Tornquist, 2011:634).

À dimensão militante e acadêmica soma-se a proximidade com o grupo, pois a pesquisadora da área da saúde, que teve reproduzido ao longo do texto parte de seu Currículo Lattes, é apontada por sua participação na REF enquanto membro do comitê editorial (1992-1994), parecerista ad hoc, autora de artigos e resenhas, além de coordenadora de dossiê..$^{20}$

Essa proximidade permitiu, então, considerações sobre o mérito acadêmico, a identidade e a alteridade, ao referenciarem "seu cuidado em textos primorosos, baseados sempre em farta $e$ minuciosa pesquisa historiográfica" e que eram "apresentados em nossos congressos acadêmicos e feministas" (grifo meu), além da "grande gentileza e humildade, atributos que hoje têm escasseado no mundo universitário, no qual pressa e arrogância parecem sempre ser os principais convidados" (Lago, Tornquist, 2011:636).

Maria Cristina Aranha Bruschini, por sua vez, é homenageada com um texto referenciado como "In Memoriam", escrito por Luzinete Simões Minella (vol. 20, $\mathrm{n}^{\circ}$ 1/2012) e a publicação, no mesmo número, de um artigo da pesquisadora, em co-autoria com Arlene Martinez Ricoldi, intitulado "Revendo estereótipos: o papel dos homens no trabalho doméstico".

E a "linhagem" dentro do grupo é explicitada:
A lacuna deixada pela sua perda soma-se àquela representada pelo falecimento das sociólogas Maria Isabel Baltar da Rocha, em 2008, e de Heleieth Saffioti, em 2010, da psicóloga Karin Ellen Von Smigay e da historiadora Maria Lúcia Mott, em 2011, também homenageadas pela REF (Minella, 2012:289).

\footnotetext{
20 "Além de ter trabalhado na avaliação de muitos artigos como parecerista ad hoc da revista por todos esses anos, Maria Lúcia publicou artigos no volume $2, \mathrm{n}^{\circ}$ 2/1994 ('Mme. Durocher, modista e parteira') e no volume 7, nº 1 e 2/1999 ('A parte ignorante: um erro de diagnóstico médico?'). Tendo publicado também resenha na revista ( $n^{\circ}$ 2/1994), em 2002 (volume 10, $n^{\circ}$ 2) foi responsável pela organização do Dossiê 'Parto', que traz seu artigo 'Bibliografia comentada sobre a assistência ao parto no Brasil (1972-2002)'” (Lago; Tornquist, 2001:635).
} 
A homenagem póstuma apresenta a carreira acadêmica da socióloga e os vínculos institucionais desenvolvidos pela sua atuação como intelectual e como militante, $e$ reafirma sua inserção na rede de relações do feminismo vinculado à $R E F$ - tanto que o mesmo número também contém artigo seu em co-autoria com Arlene Martinez Ricoldi:

Capaz de fundamentar suas refinadas análises em pesquisas que aliaram, de modo criativo, procedimentos qualitativos $e$ quantitativos, Cristina elaborou inúmeros artigos disponíveis em periódicos científicos, capítulos de livros, e organizou várias coletâneas que constituem referência obrigatória na área, tendo compartilhado a autoria tanto com parceiras de geração quanto com novas gerações de pesquisadoras (Minella, 2012:290).

O obituário da historiadora e antropóloga Miriam Lifchitz Moreira Leite (vol. 21, n 1/2013), escrito por Francirosy Campos Barbosa Ferreira, referenciado como "In Memoriam" e com duas páginas de extensão, é precedido por uma confissão da autora:

Quase declinei do pedido para escrever este obituário, por dois motivos. O primeiro por estar ainda sob o efeito da perda, ausência-presença desta que marcou minha vida acadêmica; segundo, porque, em 2010, ela me ligou para ir a sua casa, pois precisava da minha ajuda para organizar seu material. A verdade é que ela queria me presentear com a sua coleção da Revista Estudos Feministas. Hoje retribuo este presente de forma "absurda", como ela mesma me escreveria (Ferreira, 2013:209).

Após os dados pessoais, como as datas de nascimento $e$ morte (17 de maio de 1926 - 16 de fevereiro de 2013), o local de origem (Santos) e os vínculos familiares (foi casada com Dante Moreira Leite, que falecera antes dela, deixou dois filhos e quatro netos), desenrola-se a descrição de suas realizações intelectuais (as 
pesquisas multidisciplinares, a produção de 15 livros, mais de 30 artigos acadêmicos, além de contos, poemas e outros textos).

Ferreira (2013) faz um pequeno resumo de obras que considera mais importantes da autora, e vaticina:

Sua grande contribuição à história do feminismo pode ser lida em Outra face do feminismo... e Maria Lacerda de Moura, uma feminista utópica. O levantamento de documentação bibliográfica sobre Maria Lacerda de Moura coloca em relevo o trabalho historiográfico e detido de Miriam Moreira Leite. Por meio da história de vida de uma professora primária, engajada em causas nas quais a mulher não era convocada a dar sua opinião, Miriam revela-nos a repressão da família, do Estado e da Igreja ao corpo da mulher na época (Ferreira, 2013:210).

Depois de recomendar alguns links que trariam informações sobre a obra da personagem ${ }^{21}$, Ferreira (2013:210) recomenda, de forma afetiva, o contato com a obra literária da personagem através do livro de contos Roteiros inconscientes. "Eu, particularmente, chamaria atenção para os contos 'Ovo vermelho' e "A lama e o pó"'.

Entre os obituários analisados até aqui, o texto de Ferreira (2013) é aquele em que mais transparece a proximidade entre

${ }^{21} \mathrm{O}$ vídeo baseado no livro Maria Lacerda de Moura - trajetória de uma rebelde ( http://vimeo.com/35898796 ); duas entrevistas, uma sobre o vídeo publicada na revista feminista cadernos pagu, em 2004, (http://www.ScIELO.br/pdf/cpa/n22/n22a12.pdf), realizada por Mônica Raisa Schpun e que, segundo a entrevistadora, foi pensada após ela, junto com Miriam e Maria Lucia Mott assistirem ao documentário na casa desta última, e outra entrevista, focando questões da relação entre memória e fotografia realizada por Andréa Barbosa, Ana Lúcia Marques Camargo Ferraz e a própria Francirosy Ferreira, publicada na Revista Anthropológicas (http://www.ufpe.br/revistaanthropologicas/index.php/revista/article/view/139/12), em 2009; além de um documentário sobre a historiadora e antropóloga intitulado Caminhos da Memória - Miriam Moreira Leite (http://vimeo.com/35325369). 
autora e personagem, com uma significativa dimensão vivencial na descrição da trajetória, e na qual o vínculo acadêmico é apresentado como maior do que o da militância.

Gabriela Silva Leite (vol. 21, n 3/2013) também teve seu falecimento informado em texto referenciado como "In Memoriam", de autoria de Letícia Cardoso Barreto, e sua trajetória é narrada do nascimento à morte, ao mesmo tempo que representa uma ruptura com os personagens anteriores, pois nesse caso a prática militante não se entrelaça com a atividade acadêmica. Já no primeiro parágrafo, Barreto (2013) afirma a especificidade dessa mulher, ali homenageada pela REF, que era casada, tinha duas filhas, uma neta e um enteado, enfrentava há algum tempo um câncer e militava pelos direitos das prostitutas.

A dimensão biográfica se explicita, no segundo parágrafo, na rápida narrativa do percurso entre o nascimento e a prostituição:

Filha de uma família de classe média de São Paulo, formada por uma dona de casa e um crupiê, Gabriela Leite nasceu em 1951 e foi registrada como Otília Silva Leite. Em 1969 ingressou no curso de Ciências Sociais da Universidade de São Paulo, mas não o concluiu e logo o trocou pelos atrativos da vida boêmia. Tornou-se prostituta e começou a adotar o nome Gabriela, pelo qual passou a ser reconhecida ao longo de toda sua vida. Transitou pelos mais diversos territórios de prostituição em cidades como São Paulo, Rio de Janeiro e Belo Horizonte. A partir daí, essa foi a profissão pela qual gostaria de ser identificada, mesmo tendo abandonado o seu exercício na década de 1980, denominando-se uma "puta aposentada" (Barreto, 2013:945).

A seguir se desenvolvem a exposição e considerações sobre a prática militante da personagem a partir de seu protagonismo em eventos, organizações, iniciativas diversas para 0 
reconhecimento profissional e a afirmação de direitos de "profissionais do sexo". ${ }^{22}$

A dimensão intelectual da personagem também é destacada, pois ela "escreveu dois livros ao longo de sua vida: $E u$, mulher da vida, de 1992, e Filha, mãe, avó e puta, de 2009, o qual deu origem a uma peça de teatro homônima" e desejava ser "reconhecida como feminista, embora sempre destacasse os embates travados com as que ela chamava de feministas ortodoxas, que achavam que as prostitutas eram vítimas do machismo a serem resgatadas" (Barreto, 2013:946).

A autora não só reconhece uma afinidade intelectual com a personagem, por também entender a sua luta como uma ação feminista $e$ se opor a qualquer ideia abolicionista e vitimizante (defendendo a liberdade e o protagonismo das prostitutas enquanto sujeitos de sua própria história), como de certa forma afirma, pela própria existência desse obituário naquela publicação, o respeito de sua editoria para com a personagem e sua trajetória, o que, no mínimo, insere a $R E F$ dentro de um tipo de feminismo menos "ortodoxo".

No mesmo número da $R E F$ em que há o obituário de Gabriela Silva Leite encontra-se também Tributo a Helen Safa (vol. 21, $n^{\circ}$ 3/2013) escrito por Mary Garcia Castro, sobre a antropóloga norte-americana que se definia "feminista marxista".

A partir do vínculo afetivo $e$ intelectual entre a autora $e$ a personagem, o obituário busca assinalar o comprometimento militante e o rigor acadêmico presente naquela trajetória:

Com corajosa postura política, promoveu intercâmbio de acadêmicos cubanos, porto-riquenhos e de esquerda, sendo ameaçada de morte por terroristas gusanos. Com sua produção intelectual e seu ativismo em prol dos direitos dos povos não antenados com o Império, questionou a

\footnotetext{
${ }^{22}$ As principais bandeiras dessa luta seriam: "o reconhecimento legal da profissão, a identificação das prostitutas como sujeitas capazes de autodeterminação e o fim da criminalização do entorno da atividade" (Barreto, 2013:945).
} 
separação entre rigor científico e tomar partido, ou seja, o comumente desqualificado trabalho "ideológico" na academia (Castro, 2013:947).

Castro (2013:947) externa os vínculos e o afeto pela personagem, em uma narrativa que se norteia pela admiração $e$ respeito, de forma bastante próxima:

Tive o grande privilégio de conviver com Helen Safa, de ser sua amiga e de aprender muito com seus trabalhos e com sua postura/coerência de vida. Helen Safa fez parte da célebre geração de antropólogos dos anos de 1950 da Universidade de Columbia, que deixou marca singular tanto por escritos como atos e dignidade. Helen não fez concessões. Com ela se vai mais um membro de uma geração de acadêmicos que nos honra e nos deu, com sua história de vida, o ânimo para acreditar que é possível, ainda que exija sacrifícios, fazer ciência com razão, coração e principalmente com compromisso contra desigualdades $e$ injustiças sociais.

Em 2014 a REF publicou três obituários, um em cada número, sendo homenageadas Nicole-Claude Mathieu (vol. 22, $\mathrm{n}^{\circ}$ 1/2014), com texto de oito páginas (duas de texto e seis de um curriculum vitae) escrito por Vinicius Kauê Ferreira; Rose Marie Muraro (vol. 22, n²/2014), com duas páginas escritas por Luciana Zucco e Teresa Kleba Lisboa; e Fulvia Rosemberg (vol. 22, $\mathrm{n}^{\circ}$ 3/2014), com sete páginas, de autoria de Jorge Lyra e Benedito Medrado.

Nicole-Claude Mathieu é a primeira personagem a ser retratada por um homem, no conjunto analisado, e o narrador, em consonância com a crítica ao caráter androcêntrico dos estudos sobre gênero e sexo empreendidos pela antropóloga 
francesa, grafa de forma indeterminada a categoria de seu público ("sxs leitorxs"). ${ }^{23}$

Como herdeiro das tensões teórico-intelectuais da personagem, e aparentemente buscando legitimar a relevância teórico-epistemológica desta, o autor se utiliza da grafia "não androcêntrica" que substitui a declinação gramatical de gênero, com a terminação "o" ou "a" por "x", ao longo do texto. ${ }^{24}$ Adiciona uma bibliografia de dois volumes ao obituário e lista, ao longo de seis páginas e meia, as publicações da personagem.

Há um esforço de hagiografia intelectual como, por exemplo, afirmar de forma superlativa que um texto da personagem, "Quand céder n'est pas consentir" ["Quando ceder não é consentir"], de 1985, não só é um "clássico" como "marcou gerações de pesquisadoras e pesquisadores" (Ferreira, 2014:335).

Considerando-se a inevitável questão da delimitação do auditório no campo retórico, é possível entender o obituário, não só na $R E F$, mas também em outras publicações acadêmicas, que por sua própria natureza se dirigem a um público delimitado de especialistas, em um ritual grupal de homenagear uma personagem e uma obra conhecidas, consagradas e aceitas por todos.

\footnotetext{
23 "Na década de 1980, momento em que o feminismo lutava por reconhecimento no meio acadêmico na França, Mathieu escrevia que a etnologia de então tratava os homens estudados como seres eminentemente sociais, enquanto relegava às mulheres o lugar da natureza. De modo pertinente, a antropóloga sublinhava o lugar marginalizado concedido às mulheres nas etnografias de então, que raramente apareciam como informantes dxs etnólogxs em trabalhos de campo. Estranhando a ausência da perspectiva das mulheres sobre suas próprias vidas, Mathieu se perguntava se existiria alguma sociedade, ao menos conhecida, na qual as mulheres não falavam" (Ferreira, 2014:335).

24 "Seus textos representam uma contribuição essencial ao feminismo e à antropologia, sobretudo no que tange ao debate sobre a emancipação política de sujeitxs marginalizadxs. A sua noção de dominação está refletida na obra de outrxs autorxs fundamentais, e sua crítica à composição androcêntrica da comunidade antropológica de sua época são expressões contumazes da vivacidade de seu pensamento" (Ferreira, 2014:336).
} 
O texto de Ferreira (2014), no entanto, parece carregar uma preocupação na divulgação da obra, com sua longa lista de publicações da personagem, como se fossem pouco conhecidas e/ou igualmente significativas, e talvez um desejo de marcar posição de certas perspectivas no interior do próprio grupo, ao se valer de uma forte adjetivação que se faz ausente em todos os casos anteriores.

O texto a quatro mãos, de duas páginas, de Zucco e Lisboa (2014) sobre Rose Marie Muraro, com o subtítulo "uma mulher impossivel", apresenta a personagem enquanto pioneira feminista, frisando as contestações que enfrentou e a sua "personalidade marcante e sensível". A dimensão privada somente é lembrada pela referência à maternidade, $e$ as "agressões e preconceitos" que sofreu não são nomeados, ao mesmo tempo que a sua produção intelectual e o seu protagonismo são valorados como "sem precedentes":

Mulher, mãe de cinco filhos, escritora, intelectual perspicaz e feminista, foi realmente uma "mulher impossível". Desnaturalizou valores, denunciou injustiças e "gritou" a inexistência de um padrão feminino, lutando pela liberdade e autonomia das mulheres. (...) Intelectual apaixonada pelas letras, publicou mais de 40 livros, inúmeros artigos $e$ poesias, além de editorar aproximadamente 1.600 livros. Trabalhou na editora Vozes e fundou suas próprias editoras, denominadas Editora Forense Universitária (1965) e Rosa dos Tempos (1990), sendo esta a primeira editora de mulheres do Brasil. Nos últimos tempos, dedicava-se ao Instituto Cultural Rose Marie Muraro, fundado em 2009, que funciona em um imóvel cedido pelo Patrimônio Histórico da União (Zucco; Lisboa, 2014:563).

As autoras citam as obras mais significativas, elencam os prêmios, afirmam a memória, expressam o agradecimento pelas realizações, e encerram o texto com um poema da personagem que faz referências à vida e à morte. 
Finalmente, o último obituário do período estudado, o de Fulvia Rosemberg, com sete páginas, recebe um subtítulo: "memórias a partir do lugar do afeto". ${ }^{25}$

O subtítulo faz jus ao texto, pois Lira e Medrado iniciam a narrativa identificando o lugar de onde falam e os limites de sua homenagem póstuma, parcial e passional, ao confessarem a surpresa pelo convite de escreverem o obituário, a dúvida quanto ao merecimento e à capacidade para tal tarefa, $e$ o incentivo por parte de Márcia Laranjeira (Jacomé) e de Júlia, filha da personagem (Lira; Medrado, 2014:905).

O texto, extenso em comparação à média da revista, identifica as contribuições da personagem

para nossas vidas, para o movimento feminista, para o campo de defesa dos direitos da criança, para as políticas de promoção da igualdade racial e para o campo da docência e dos estudos e pesquisas em psicologia social. Fúlvia foi uma das grandes defensoras de uma educação infantil de qualidade e do direito à creche; desenvolveu $e$ orientou uma série de pesquisas sobre gênero, raça e idade; dedicou-se a pesquisar oportunidades educacionais brasileiras da ótica de gênero e raça; coordenou a sessão brasileira do Programa Internacional de Bolsas de PósGraduação da Fundação Ford, que assumiu, no Brasil, a configuração de um Programa de Ação Afirmativa (AA) para negros e indígenas, entre outros segmentos sociais. Ela não apenas fez, como ensinou e apoiou outros fazeres (Lira; Medrado, 2014:905).

A personagem foi uma das fundadoras de um importante jornal feminista da década de 80, o Mulherio ${ }^{26}$, voltado para

\footnotetext{
${ }^{25}$ Entre todos os obituários abordados aqui, este é um dos três que apresentam fotografia da personagem, os outros são o de Miriam Lifchitz Moreira Leite (vol. 21, n 1/2013) e Ana Alice Alcântara Costa (vol. 23, n 1/2015).

${ }^{26}$ Conforme a nota 2 do texto: "O Mulherio tinha como editoras Fúlvia e Adélia Borges. O conselho editorial (informado na edição 0) era composto por: Carmem Barroso, Carmem da Silva, Cristina Bruschini, Elizabeth Souza Lobo, Eva
} 
profissionais de comunicação, grupos de mulheres e entidades culturais $e$ acadêmicas, $e$ professora da pós-graduação em Psicologia Social na PUC-SP.

O obituário traça um retrato carinhoso, mas as idiossincrasias não são atenuadas, e sobre o episódio do primeiro contato entre os autores e a personagem a lembrança evocada conclui que:

\begin{abstract}
é preciso reconhecer que não foi agradável. Ela nos recebeu com poucas e assertivas palavras, que nos foram sentidas, naquele momento, como rudes. (...) A forma direta $e$ o discurso orientado pela justiça e pela equidade foi uma marca desta e de todas as outras inúmeras conversas que tivemos com Fúlvia. (...) De fato, ela não era uma "pessoa fácil". Como dissemos em outro texto, esse talvez fosse seu maior encanto. Ela não se oferecia gratuitamente. Precisava ser conquistada. Ela também jamais pedia algo, precisava conquistar, fazia por merecer (Lira; Medrado, 2014:907).
\end{abstract}

E na demonstração da proximidade, visto que Jorge Lira foi seu orientando e Benedito Medrado seu aluno, tendo ambos se tornado amigos da homenageada, a gratidão também se faz presente em diversas passagens, como por exemplo:

Foi Fúlvia quem nos apresentou as leituras, as pessoas e as instituições de maior referência no feminismo brasileiro $e$ internacional. Foi ela quem nos falou, com vigor, que ciência, arte e política são campos com regras e processos

\footnotetext{
Alterman Blay, Fúlvia Rosemberg, Heleieth Saffioti, Lélia Gonzales, Maria Carneiro da Cunha, Maria Moraes, Maria Malta Campos, Maria Rita Kehl, Maria Valéria Junho Penha, Marilia de Andrade, Marisa Corrêa e Ruth Cardoso. O projeto gráfico era de Derly Barroso, e a jornalista responsável, Adélia Borges. O acervo desse periódico está completamente disponível no site da FCC (www.fcc.org.br/conteudosespeciais/mulherio)" (Lira; Medrado, 2014:906). Em itálico nomes de membros que receberam obituários no período aqui abordado, demonstrando a existência de uma memória feminista e de certa vinculação grupal entre seus participantes.
} 
particulares, mas que dialogam e se afetam mutuamente. Foi ela quem nos apresentou Johannes Vermeer, um pintor holandês que teve uma vida curta (1632-1675) e uma produção pequena, mas de beleza rara e estilo, cor e luz inconfundíveis. (...) Foi Fúlvia também quem nos incentivou a fundar o Instituto PAPAI e o Gema/UFPE e a seguir no desenvolvimento de pesquisa $e$ outras intervenções políticas sobre homens e masculinidades, a partir da perspectiva feminista de gênero. (...) Quem teve o prazer de ler as produções de Fúlvia e conviver com ela, há de concordar conosco que Fúlvia era, na mesma medida, exigente e cuidadosa. Apaixonada e apaixonante. Gostava de quem tinha paixão pela vida, como ela (Lira; Medrado, 2014:908).

Há uma clara dimensão memorialística do texto, de certo lirismo, e o vínculo afetivo se sobrepõe sobre as questões profissionais e institucionais - como quando faz referência a uma situação na qual alguém, em uma mesa de bar, iria tecer considerações críticas sobre Luiz Mott e ela de forma ética identificou-se antecipadamente como irmã do polêmico antropólogo e militante do movimento homossexual, ou na ocasião de uma visita na qual ambos os autores prepararam um jantar, desses que são pensados e organizados com detalhes $e$ cuidados, para ela, que, antes de fazerem a refeição, perguntou se eram amigos e, frente a resposta positiva, confessou não gostar do prato preparado (bacalhau), ou ainda, na referência aos versos de Florbela Espanca que falam sobre a primavera em cada vida $e$ que deve ser cantada de forma florida (Lira; Medrado, 2014).

$E$ como que se equilibrando entre o afetivo e o institucional o texto se encerra com um poema intitulado "Irmã ausente na visita à casa paterna", escrito por Carmem Barroso em homenagem à personagem, e uma reprodução do resumo de seu perfil profissional no Currículo Lattes. 


\section{Considerações sem um fim}

Segundo Jorge Luis Borges, na religião oriental do shintoismo é dado a cada homem ou mulher ser um Deus, desde que sua lembrança não desapareça. O obituário, enquanto exercício de memória grupal, permite transformar cada membro do grupo, por seus vínculos afetivos, intelectuais ou institucionais, a partir de sua memória em parte de um forte amálgama simbólico. E a partir do exposto podemos pensar essa forma particular de memória a partir de três questões que nos parecem dignas de reflexão. A primeira deriva da constatação de que a existência de uma narrativa funerária supõe a ampla utilização de forças sociais pela manutenção de uma memória, ou certo tipo de memória, no qual um indivíduo é não somente uma unidade, mas parte de um grupo e a representação de ideais e expectativas que já não são subterrâneas, e que convivem junto a outras manifestações de superfície - e tal fato se apresenta em relação ao nosso recorte pela amplitude e diversidade do que possa vir a ser o feminismo.

A segunda, desdobrada da constatação de que esse indivíduo encarado como notável também está situado em um campo de disputa no qual memória e esquecimento se estabelecem em relação a sua trajetória e a de outros de seu mesmo grupo.

$\mathrm{E}$, finalmente, as transformações históricas e sociais podem privilegiar diferentes notáveis em diferentes contextos. Mesmo a "memória oficial" se altera ou se mostra capaz de incorporar variantes ou mesmo contradições.

Enquanto texto de autoria definida, dentro de uma publicação e com um objetivo, os obituários representam ao mesmo tempo o externar a dor da ruptura que surge a partir da trajetória e das vivências de quem escreve e a obrigação de ofício de reverenciar personagens que se vinculam aos valores $e$ ideais do grupo.

Ainda que reconhecendo uma inevitável heterogeneidade de valores, de estilos, de formas de vivenciar a dor e da 
capacidade de expressão de cada autor, os textos representam sinais ao nível institucional um ethos feminista e militante que a $R E F$ constantemente reafirma enquanto grupo institucionalizado.

Um exemplo curioso é o conjunto de obituários de 2014, sobre Rose Marie Muraro (vol. 22, $\mathrm{n}^{\circ}$ 1/2014), Nicole-Claude Mathieu (vol. 22, n²/2014) e Fulvia Rosemberg (vol. 22, n 3/2014), todos com o discurso de homenagem que caracteriza o gênero, mas a pioneira intelectual $e$ militante carioca, com obras $e$ realizações "sem precedentes", recebeu o mesmo espaço padrão da maioria dos obituários da REF ou seja, duas páginas, a antropóloga francesa, autora de um texto "clássico", foi retratada em oito páginas, sendo que a maioria delas era uma listagem de obras, e a psicóloga paulista foi retratada, ao longo de sete páginas, em um dos textos mais emotivos dentre os aqui analisados.

Essa diferença serve como ponto de discussão sobre em que medida os textos representam não só a construção de uma memória do feminismo, como também dos grupos ligados à revista, assim como reflexo de decisões editoriais e das vinculações dos autores dos textos com os personagens e suas trajetórias.

Entre o caráter claramente informativo e com ênfase na obra do texto sobre Gloria Evangelina Anzaldúa e a escrita de si presente nas narrativas sobre Miriam Lifchitz Moreira Leite e Helen Safa, na inclusão de deliciosas entrevistas para homenagearem Heloneida Studart e Heleieth Saffioti, ou ainda, a inclusão, entre tantas acadêmicas militantes, de Gabriela Silva Leite, uma "puta aposentada", entre outros exemplos possíveis, mostra-se o emaranhado de ideias e afetos presentes no interior da revista $e$ que, para além de divergências possíveis, são partilhados pela maioria de seus membros.

Deve-se perceber as características dessas experiências de recordação e exposição das experiências individuais, na fusão de lembrança e avaliação, destinada a responder as indagações de um grupo de leitores que é ao mesmo tempo impessoal, mas socialmente delimitado, pela proximidade/vínculo/reconhecimento 
de indivíduos que ocupam posições sociais inter-relacionadas em diferentes níveis.

A escrita de si, presente em muitos dos textos, com maior ênfase em uns do que em outros, talvez esteja ligada a uma maior absorção pelo campo intelectual das implicações da virada linguística ou, ainda, represente tanto traços estilísticos de cada autor como também uma prática discursiva consolidada em sua área de atuação acadêmica de origem.

Dessa forma, se explicitam "eventos marcantes", "episódios nucleares", "memórias definidoras do self , e "memórias vívidas" que são expostos como referenciais de identidade pessoal $e$ profissional, reconhecimento de uma experiência/vivência, ou, ainda, percepção de uma trajetória coletiva e singular. Nesse sentido, se situando para além dos objetivos deste trabalho, comparar a prática de obituários em publicações de mesma natureza ou dos mesmos personagens em outras publicações poderia se tornar um exercício intelectual bastante rico e curioso.

Com certeza esse tipo de fonte oferece amplas possibilidades de interpretação das dinâmicas grupais dos processos de criação ou manutenção de identidades, da consolidação de heranças intelectuais e políticas, de manutenção da memória, entre outros aspectos da história intelectual.

Quem viver, verá!

\section{Referências bibliográficas}

Amoussy, Ruth (org.). Imagens de si no discurso: a construção do ethos. São Paulo, Contexto, 2005.

BENJAMIM, Walter. O narrador: considerações sobre a obra de Nikolai Leskov. In: BENJAMIM, Walter. Magia e técnica, arte e política: ensaios sobre literatura e história da cultura. Obras escolhidas, vol. 1, São Paulo, Brasiliense, 1994, pp.197-221.

BerTonI, Estevão. Maria Lúcia de Barros Mott de Melo Souza (19482011): Cuca Mott, historiadora e escritora. Folha de S. Paulo, Cotidiano, 01 de julho de 2011. 
BouRdiEU, Pierre. A ilusão biográfica. In: FerReIRA, Marieta de Moraes; AMADO, Janaína (org.). Usos \& abusos da história oral. Rio de Janeiro, Fundação Getúlio Vargas, 1996, pp.181-191.

COSTA, Luciano Martins. Entrevista / Matinas Suzuki Jr.: Reportagem + biografia + arte $=$ obituário. Observatório da imprensa, 19 de fevereiro de

2008

[http://www.observatoriodaimprensa.com.br/artigos.asp? $\operatorname{cod}=473 \mathrm{FD}$ S001 - acesso em 19 fev. 2009].

DERRIDA, Jacques. Memorias para Paul de Man. Barcelona, Gedisa, 1998

Douglas, Mary. Como as instituições pensam. São Paulo, Editora da Universidade de São Paulo, 1998.

EID, Mushira. The world of obituaries: gender across cultures and over time. Detroit, Wayne State University Press, 2002.

FABRE, Michel. Fazer de sua vida uma obra. Educação em Revista, Belo Horizonte, UFMG, vol. 27, n 1 , abril, 2011, pp.347-368.

FAIRClOUGH, Norman. Discurso e mudança social. Brasília, Editora UnB, 2001.

FOWLER, Bridgit. Obituary as collective memory. New York, Outledge, 2007.

Fulton, Robert L.; BENDIKSON, Robert. Death and identity. Philadelphia, Charles Press, 1994.

GOFFMAN, Erving. On face-work: an analysis of ritual elements in social interaction, In: GOFFMAN, Erving. Interaction Ritual: Essays on face-toface behavior. New York, Anchor Books, 1967, pp.5-45.

GrossI, Miriam Pillar. A Revista Estudos Feministas faz 10 anos: uma breve história do feminismo no Brasil. Revista Estudos Feministas, Florianópolis, vol. 12, $\mathrm{n}^{\circ}$ especial, dezembro, 2004, pp.211-221 [http://www.ScIELO.br/SclELO.php?script =sci_arttext\&pid=S0104026X2004000300023\&lng $=e n \& n r m=$ iso $\quad-$ acesso em 04 maio 2015].

GUTHKE, Karl S. Epitaphs culture in the West: variations on a theme in cultural history. United Kingdom, The Edwin Mellen Press, 2003. 
KouRY, Mauro Guilherme Pinheiro. A dor como objeto de pesquisa social. Ilha: Revista de Antropologia, Florianópolis, vol. $1, \mathrm{n}^{\circ} 0$, out.1999, pp.71-83.

KouRY, Mauro Guilherme Pinheiro. O luto no Brasil no final do século XX. Caderno CRH, Salvador, UFBA, vol.27, n72, 2014, pp.593-612.

KouRY, Mauro Guilherme Pinheiro. Sociologia da emoção: o Brasil urbano sob a ótica do luto. Petrópolis, Vozes, 2003.

LAGO, Mara Coelho de Souza. Narrar a REF e fazer a REF: uma história coletiva. Revista Estudos Feministas, Florianópolis, vol. 21, $\mathrm{n}^{\circ} 2$, 2013, pp.643-653.

LEONZO, Nanci. O culto aos mortos no século XIX: os necrológios. In: Martins, José de Souza (org.). A morte e os mortos na sociedade brasileira. São Paulo, Hucitec, 1983, pp.86-84.

MaInguenteAu, Dominique. A propósito do ethos. In: MotTA, Ana Raquel. Salgado, Luciana (org.). Ethos discursivo. São Paulo, Contexto, 2008, pp.11-29.

MALUF, Sônia Weidner. Os dossiês da REF: além das fronteiras entre academia e militância. Revista Estudos Feministas, Florianópolis, v. 12, setembro-dezembro, 2004, pp.235-243.

MARTINEZ, Monica. A vida em 20 linhas: a representação da morte nas páginas da Folha de S. Paulo. Intercom: Revista Brasileira de Ciência da Comunicação, São Paulo, vol.37, n 2, 2014, pp.71-90.

MetCAlf, Peter; HunTigton, Richard. Celebrations death: anthropology of post mortem. Discourse and society, vol.13, n ${ }^{\circ} 4,2002$, pp.495536.

MINELLA, Luzinete S. Fazer a REF é fazer política: memórias de uma metamorfose editorial. Revista Estudos Feministas, vol. 16, $\mathrm{n}^{\circ} 1$, Florianópolis, 2008, pp.105-116.

MOORE, Stephen H. Disinterring ideology from a corpus of obituaries: a critical Mortuary Ritual. Cambridge, Cambridge University Press, 1991.

MOTTA, Antonio. À flor da pedra: formas tumulares e processos sociais nos cemitérios brasileiros. Recife, Fundação Joaquim Nabuco. Ed. Massangana, 2008. 
REvista Estudos Feministas. Seção Especial REF 20 anos. Revista Estudos Feministas, vol. 21, $\mathrm{n}^{\circ}$ 2, Florianópolis, maio/ago 2013, pp.573-653.

SANTANA, Fabíola de J. S. A retórica fúnebre: uma abordagem históricodiscursiva de epitáfios, obituários e memoriais virtuais. Tese (Doutorado em Linguística), UFPE, Recife, 2011.

SCARPIN, Paulo. A logística de fazer um morto. Revista Piauí, no 17, São Paulo, fev. 2008 [http://www.revistapiaui.com/edicao-17/esquina/alogistica-de-fazer-um-morto - acesso em 20 abril 2015].

SCAVONE, Lucila. Perfil da REF dos anos 1999-2012. Revista Estudos Feministas, vol. 21, n² 2, Florianópolis, 2013, pp.587-596.

SUZUKI JR., Matinas (org.). Livro das vidas: obituários do New York Times. São Paulo, Companhia das letras, 2008.

\section{Fontes}

BARRETO, Letícia Cardoso. Gabriela Silva Leite. Revista Estudos Feministas, Florianópolis, vol. 21, n 3, 2013, pp.945-947.

CASTRO, Mary Garcia. Tributo a Helen Safa. Revista Estudos Feministas, Florianópolis, vol. 21, n³, 2013, pp.945-947.

CostA, Claudia de Lima. Gloria Evangelina Anzaldúa. Revista Estudos Feministas, Florianópolis, vol. 12, n ${ }^{\circ}$, abril, 2004, pp.13-14.

CunHA, Cecília. Uma Homenagem a Heloneida Studart, Revista Estudos Feministas, Florianópolis, vol. 16, n ${ }^{\circ}$ 1, 2008, pp.271-276;

DUARTE, Ana Rita Fonteles. Betty Friedan: morre a feminista que estremeceu a América. Revista Estudos Feministas, Florianópolis, vol. 14, $\mathrm{n}^{\circ} 1$, abril, 2006, pp.287-293.

FERREIRA, Francirosy Campos Barbosa. Miriam Lifchitz Moreira Leite. Revista Estudos Feministas, Florianópolis, vol. 21, n ${ }^{\circ}$ 1, abril, 2013, pp.209-210.

FerREIRA, Vinicius Kauê. Nicole-Claude Mathieu: Elle n'est plus. Revista Estudos Feministas, Florianópolis, vol. $22, \mathrm{n}^{\circ}$ 1, abril, 2014, pp.335342. 
LAGO, Mara Coelho de Souza. Tornquist, Carmen Susana. Maria Lúcia de Barros Mott: pesquisadora militante. Revista Estudos Feministas, Florianópolis, vol. 19, $\mathrm{n}^{\circ}$ 2, agosto, 2011, pp.634-636.

LYRA, Jorge; MEDRADO, Benedito. Fulvia Rosemberg: memórias a partir do lugar do afeto. Revista Estudos Feministas, Florianópolis, vol. 22, n ${ }^{\circ}$ 3, dezembro, 2014, pp.905-909.

MENDES, Juliana Cavilha; BECKER, Simone. Entrevista com Heleieth Saffioti. Revista Estudos Feministas, Florianópolis, v. 19, n ${ }^{\circ} 1$, abril, 2011, pp.143-166.

Minella, Luzinete Simões. Heleieth Saffioti, uma pioneira dos estudos feministas no Brasil. Revista Estudos Feministas, Florianópolis, vol. 19, n 1 , abril, 2011, pp.141-143.

, Luzinete Simões. Maria Cristina Aranha Bruschini: uma trajetória brilhante. Revista Estudos Feministas, Florianópolis, vol. 20, n ${ }^{\circ}$ 1, abril, 2012, pp.289-290.

, Luzinete Simões. Maria Isabel Baltar da Rocha Rodrigues: fazendo da ciência uma política. Revista Estudos Feministas, Florianópolis, vol. 16, $\mathrm{n}^{\circ}$ 3, dezembro, 2008, pp.1135-1137.

NECKEL, Roselane. "Entra, menino", "Xô, galinha" e "Sim, senhor!": entrevista com Heloneida Studart. Revista Estudos Feministas, Florianópolis, vol.16, $\mathrm{n}^{\circ}$ 1, 2008, pp.265-269.

Revista Estudos Feministas, Nota de Falecimento: Heleieth Saffioti. Florianópolis, vol.18, $\mathrm{n}^{\circ}$ 3, setembro/dezembro, 2010, pp.652.

Nota de Falecimento de Nara Araújo. Florianópolis, vol. 16, $\mathrm{n}^{\circ}$ 3, dezembro, 2008, pp.1138.

. Nota de Falecimento: Karin Ellen Von Smigay (1948-2011). Florianópolis, vol. 19, $\mathrm{n}^{\circ}$ 1, abril, 2011, pp.34.

SARDENBERG, Cecilia M. B.. Ana Alice Alcântara Costa: "guerreira e forte para todo o sempre" (1951-2014 Revista Estudos Feministas, Florianópolis, vol.23, $\mathrm{n}^{\circ}$ 1, 2015, pp.151-155.

ZuCCO, Luciana; LiSBOA, Teresa Kleba. Rose Marie Muraro: uma mulher impossível. Revista Estudos Feministas, Florianópolis, vol. 22, n ${ }^{\circ}$ 2, agosto, 2014, pp.563-564. 